medRxiv preprint doi: https://doi.org/10.1101/2021.03.18.21253882; this version posted March 20, 2021. The copyright holder for this preprint (which was not certified by peer review) is the author/funder, who has granted medRxiv a license to display the preprint in perpetuity.

It is made available under a CC-BY 4.0 International license .

\title{
Temperature at conception and pregnancy loss in rural KwaZulu-Natal Province, South Africa: Implications for climate change policy in sub-Saharan African settings
}

Authors: Yoshan Moodley ${ }^{\mathrm{a}, \mathrm{b}, \mathrm{c}}$, Frank Tanser ${ }^{\mathrm{a}, \mathrm{d}, \mathrm{e}}$, Andrew Tomita ${ }^{\mathrm{c}, \mathrm{f}}$

\section{Affiliations:}

${ }^{a}$ Africa Health Research Institute, Private Bag X7, Congella 4013, KwaZulu-Natal, South Africa.

${ }^{\mathrm{b}}$ Faculty of Health and Environmental Sciences, Central University of Technology, Private Bag X20539, Bloemfontein, 9300, South Africa.

${ }^{c}$ KwaZulu-Natal Research Innovation and Sequencing Platform, University of KwaZuluNatal, Private Bag X7, Congella 4013, Kwazulu-Natal, South Africa.

${ }^{\mathrm{d}}$ Lincoln International Institute for Rural Health, University of Lincoln, Brayford Pool, Lincoln, Lincolnshire, LN6 7TS UK.

${ }^{\mathrm{e}}$ School of Nursing and Public Health, University of KwaZulu-Natal, 238 Mazisi Kunene Road, Durban 4041, South Africa.

${ }^{\mathrm{f} C e n t r e}$ for Rural Health, University of KwaZulu-Natal, 238 Mazisi Kunene Road, Durban 4041, South Africa.

\section{Correspondence:}

Yoshan Moodley (PhD)

Africa Health Research Institute

Private Bag X7

Congella 4013

South Africa

email: yoshan.moodley@ahri.org 
medRxiv preprint doi: https://doi.org/10.1101/2021.03.18.21253882; this version posted March 20, 2021. The copyright holder for this preprint (which was not certified by peer review) is the author/funder, who has granted medRxiv a license to display the preprint in perpetuity.

It is made available under a CC-BY 4.0 International license.

Tel: +27312604991

Fax: N/A

Running head: Maximum temperatures \& pregnancy loss

Word count (Abstract): 252

Word count (Text): 2132

List of Abbreviations:

AHRI: Africa Health Research Institute

95\% CI: 95\% Confidence interval

OR: Odds ratio

UNFCCC: United Nations Framework Convention on Climate Change 


\section{Abstract}

Background: Global warming is projected to cause a substantial rise in temperatures with serious health implications across sub-Saharan Africa. Although South African policy makers have drafted a climate change adaptation plan, potential health threats posed by increasing temperatures on women's reproductive health are overlooked due to the lack of local population-based evidence. We sought to address the gap in the evidence around global warming and women's reproductive health in sub-Saharan Africa by using one of the continent's largest prospective cohorts from rural KwaZulu-Natal Province, South Africa to investigate the relationship between temperature at conception and pregnancy loss.

Methods: Our study sample consisted of 36341 pregnancies from 16765 women from the uMkhanyakude District of KwaZulu-Natal, South Africa between 2000-2017. Average monthly temperatures for the study locale during the study period were obtained from the South African Weather Services. An adjusted logistic regression model was used to investigate the relationship between temperature at conception and pregnancy loss (miscarriage or stillbirth).

Results: The rate of pregnancy loss in the study sample was 1.9 (95\% Confidence interval [CI]: 1.7-2.0) per 100 pregnancies. We observed a 4\% higher odds of pregnancy loss for each $1{ }^{\circ} \mathrm{C}$ increase in temperature (Adjusted Odds Ratio: 1.04, 95\% CI: 1.01-1.08).

Conclusion: There is a clear relationship between temperature and pregnancy loss in our subSaharan African setting. The effects of global warming will likely exacerbate the existing challenges for women's reproductive health in this region. Pregnancy outcomes should be given adequate attention when sub-Saharan African governments draft policies in response to global warming. 
medRxiv preprint doi: https://doi.org/10.1101/2021.03.18.21253882; this version posted March 20, 2021. The copyright holder for this preprint (which was not certified by peer review) is the author/funder, who has granted medRxiv a license to display the preprint in perpetuity.

It is made available under a CC-BY 4.0 International license .

Keywords: Global Warming; Hot Temperature; Pregnancy Outcome; sub-Saharan Africa;

South Africa. 
medRxiv preprint doi: https://doi.org/10.1101/2021.03.18.21253882; this version posted March 20, 2021. The copyright holder for this preprint (which was not certified by peer review) is the author/funder, who has granted medRxiv a license to display the preprint in perpetuity.

It is made available under a CC-BY 4.0 International license.

\section{Introduction}

Despite the international commitments made as part of the landmark United Nations Framework Convention on Climate Change (UNFCCC) Paris Agreement to mitigate the impact of global warming on human health, most sub-Saharan African countries who have ratified the Agreement will struggle to restrict rises in national ambient temperatures below the proposed target of $1.5^{\circ} \mathrm{C}$ (Weber et al., 2018). Sub-Saharan Africa is particularly vulnerable to the hazardous effects of global warming which will likely exacerbate existing high ambient temperatures in the region. In addition, resource constraints are anticipated to hinder the effective roll-out of adaptation or mitigation strategies in sub-Saharan Africa (Weber et al., 2018; Russo et al., 2016).

Global warming is projected to cause a $6^{\circ} \mathrm{C}$ rise in maximum temperatures across South Africa by the year 2070 (Mbokodo et al., 2020), which is expected to have dire implications for the health of socially vulnerable populations in parts of the country that will likely still be reeling from the aftermath of a stubborn HIV epidemic. Several South African studies have reported an association between high ambient temperatures and an increased risk of adverse health outcomes such as mortality, heat stress, and infectious diseases (Chersich et al., 2018). South African policy makers have acknowledged this setting-specific evidence and proactively drafted a climate change adaptation plan in response to global warming and the impending increase in national maximum temperatures (Garland, 2014). Regrettably, women's reproductive health is overlooked in this plan due to the lack of local populationbased evidence (Garland, 2014). With excessively high poverty, HIV infection, and maternal mortality rates (Ngwenya et al., 2018; Vandormael et al., 2019; Tlou et al., 2017), subSaharan African women of childbearing age are a prime example of an already vulnerable population which could potentially suffer additional adverse health outcomes due to global 
medRxiv preprint doi: https://doi.org/10.1101/2021.03.18.21253882; this version posted March 20, 2021. The copyright holder for this preprint (which was not certified by peer review) is the author/funder, who has granted medRxiv a license to display the preprint in perpetuity.

It is made available under a CC-BY 4.0 International license .

warming. Although the relationship between ambient temperature and fetal health is still to be established for sub-Saharan African settings, reports from more industrialized regions of the world suggest a relationship between higher ambient temperatures and adverse pregnancy outcomes such as preterm delivery, low birth weight, and pregnancy loss (Kuehn and McCormick, 2017; Bekkar et al., 2020).

We sought to address the gap in the evidence around global warming and women's reproductive health in sub-Saharan Africa by using one of the African continent's largest prospective cohorts from rural KwaZulu-Natal, South Africa to investigate the relationship between temperature at conception and pregnancy loss.

\section{Methods}

\subsection{Study design and setting}

This was a population-based, prospective cohort study involving pregnant women from a rural community in the uMkhanyakude District of KwaZulu-Natal, South Africa. The rural community, described in detail elsewhere (Tanser et al., 2008), has been part of the Africa Health Research Institute's (AHRI's) health and demographic surveillance systems for over 20 years. The uMkhanyakude District has a high unemployment rate and relatively poor levels of service delivery (Mulopo et al., 2020). The two most important public health problems facing women of childbearing age in the uMkhanyakude District include a high HIV incidence of 3.06 seroconversion events per 100 person-years and a high maternal mortality ratio of 650 maternal deaths per 100000 live births (Vandormael et al., 2019; Tlou et al., 2017). As shown in Fig. 1, the uMkhanyakude District is located in a geographic region 
medRxiv preprint doi: https://doi.org/10.1101/2021.03.18.21253882; this version posted March 20, 2021. The copyright holder for this preprint (which was not certified by peer review) is the author/funder, who has granted medRxiv a license to display the preprint in perpetuity.

It is made available under a CC-BY 4.0 International license.

with a sub-tropical climate characterized by wet summers and dry winters (Morgenthal et al., 2006). Daily maximum temperatures in the uMkhanyakude District are usually above $20^{\circ} \mathrm{C}$ (Morgenthal et al., 2006).

\subsection{Data sources}

AHRI has conducted regular population-based surveys in the rural community since 2000.

These surveys incorporate a pregnancy questionnaire that is administered (biannual until 2011, triannual since 2012) to all women in the community who report pregnancies (Chetty et al., 2016; Chetty et al., 2017). The pregnancy questionnaire collects data on several maternal and pregnancy-related characteristics such as number of prior pregnancies, date of last menses, antenatal clinic attendance during the pregnancy, pregnancy outcome date, as well as pregnancy outcomes such as live births, number of children delivered, abortions, and stillbirths (Chetty et al., 2017).

Data for other variables which might influence pregnancy outcomes is collected in other demographic and health questionnaires that are also administered during the population-based survey (Tanser et al., 2008). This includes sociodemographic characteristics such as age, socioeconomic status based on a household asset index, marital status, and educational level; and infectious diseases which are endemic to this region of South Africa (HIV and tuberculosis). Temperature data used in the analysis was the average maximum temperature in the study locale for each month between January 2000 and December 2017 (i.e. 216 average monthly measurements over the entire study period), and was obtained from the South African Weather Services. 


\subsection{Measures}

The study outcome, pregnancy loss, was defined as a either miscarriage or stillbirth. Miscarriage was defined as a pregnancy of $<28$ weeks gestational duration (Chetty et al., 2017; Moodley et al., 2021). This was established for each pregnancy by calculating the difference in weeks between the date that the pregnancy ended and the date of the last menses. Stillbirth was collected as one of the pregnancy outcomes in the pregnancy questionnaire and was defined as delivery of a dead infant of gestational age $\geq 28$ weeks (Chetty et al., 2017; Moodley et al., 2021). The date of conception was determined using the date of the last menses. Temperature at conception was defined as the temperature corresponding to the month and year in which the pregnancy was conceived.

\subsection{Eligibility criteria}

We reviewed records from AHRI population-based surveys conducted between 2000 and 2017 for all singleton pregnancies conceived in women aged 16-35 years old. We excluded pregnancies that were electively aborted. Our study sample was comprised of 36341 pregnancies from 16765 women.

\subsection{Statistical analysis}

R version 3.6.2 (R Foundation for Statistical Computing, Vienna, Austria) was used to analyze the study data. We used descriptive statistics to summarize the distribution of various pregnancy-related and maternal characteristics in our study sample. We then performed univariate and multivariate logistic regression analyses to investigate the relationship between 
medRxiv preprint doi: https://doi.org/10.1101/2021.03.18.21253882; this version posted March 20, 2021. The copyright holder for this preprint (which was not certified by peer review) is the author/funder, who has granted medRxiv a license to display the preprint in perpetuity.

It is made available under a CC-BY 4.0 International license .

temperature at conception and pregnancy loss in our study sample. The results of our

univariate and multivariate regression analyses are presented as unadjusted and adjusted odds ratios (ORs), with $95 \%$ confidence intervals $(95 \% \mathrm{CI})$.

\subsection{Ethical approval}

AHRI's active health and demographic surveillance platform, which includes the populationbased cohort from which our study data was obtained, has been approved by the Biomedical Research Ethics Committee of the University of KwaZulu-Natal, South Africa (Protocol reference: BE290/16). All participants in the AHRI population-based surveys provided written informed consent.

\subsection{Availability of data and materials}

The datasets analyzed in this study are available on AHRI's Online Data Repository [https://data.ahri.org/index.php/home].

\section{Results}

The study sample $(\mathrm{N}=36341)$ is described in Table 1 . The rate of pregnancy loss in the study sample was 1.9 (95\% CI: 1.7-2.0) per 100 pregnancies. Of the 679 pregnancies that were lost, $395(58.2 \%)$ were miscarriages and the remaining 284 (41.8\%) were stillbirths. The average maternal age for pregnancies comprising the sample was 23.74 (95\% CI: 23.69-23.79) years. A prior history of pregnancy loss was rare $(n=979,2.7 \%)$. A maternal history of tuberculosis was also rare $(n=226,0.6 \%)$. Two-thirds of all pregnancies were in mothers from the low 
medRxiv preprint doi: https://doi.org/10.1101/2021.03.18.21253882; this version posted March 20, 2021. The copyright holder for this preprint (which was not certified by peer review) is the author/funder, who has granted medRxiv a license to display the preprint in perpetuity.

It is made available under a CC-BY 4.0 International license.

socioeconomic status group $(n=24444,67.3 \%)$. Only a small percentage of women complied with the national recommendation of attending at least eight routine antenatal clinic visits during their pregnancy $(n=522,1.4 \%)$. A large proportion of pregnancies were in unmarried mothers $(n=34662,94.8 \%)$. Half of all pregnancies were in mothers who had already completed their primary school education $(n=19117,52.6 \%)$. Lastly, 2911 pregnancies (8.0\%) occurred in mothers who were HIV-positive at the time.

Table 2 presents the results of the univariate and multivariate logistic regression analyses. Our univariate statistical analysis revealed a $5 \%$ higher odds of pregnancy loss for each $1^{\circ} \mathrm{C}$ increase in temperature at conception (unadjusted OR: 1.05, 95\% CI: 1.02-1.09). When we adjusted our analysis for potential confounders, we observed a $4 \%$ higher odds of pregnancy loss for each $1{ }^{\circ} \mathrm{C}$ increase in temperature at conception (adjusted odds ratio: $1.04,95 \% \mathrm{CI}$ : 1.01-1.08).

\section{Discussion}

Our analysis of data from one of the largest population-based cohorts on the African continent demonstrates clear relationship between increasing temperature at conception and pregnancy loss. Specifically, our adjusted statistical analysis found that the odds of pregnancy loss increased by $4 \%$ for each $1{ }^{\circ} \mathrm{C}$ increase in temperature at conception. This is, to the best of our knowledge, the first study from sub-Saharan Africa to report a relationship between increasing temperatures and adverse pregnancy outcomes. Furthermore, our findings are in general agreement with the findings of two recent systematic reviews on this subject (Kuehn and McCormick, 2017; Bekkar et al., 2020). Thus, our study findings confirm the 
medRxiv preprint doi: https://doi.org/10.1101/2021.03.18.21253882; this version posted March 20, 2021. The copyright holder for this preprint (which was not certified by peer review) is the author/funder, who has granted medRxiv a license to display the preprint in perpetuity.

It is made available under a CC-BY 4.0 International license.

importance of climate change and increasing ambient temperatures on adverse pregnancy outcomes in sub-Saharan Africa.

There are currently no South African policies responsive to the potential effects of global warming on women's reproductive health and pregnancy outcomes, and recommendation of an appropriate policy framework lies beyond the scope of our study. However, our study findings do provide sufficient impetus for an appropriate policy framework which seeks to address the impact of increasing temperatures on women's reproductive health and pregnancy outcomes to be developed by policymakers in South Africa and other sub-Saharan African countries. In the absence of this policy framework, governments in sub-Saharan Africa should consider enforcing one of the most important human rights enshrined in their national constitutional frameworks and The African Charter on Human and People's Rights access to a clean basic water supply (South African Human Rights Commission, 2018). All pregnant mothers in sub-Saharan Africa should have access to clean drinking water to prevent dehydration when ambient temperatures are high (Garland, 2014). Increased maternal water consumption during pregnancy is associated with a significantly lower risk of neural tube defects, oral clefts, musculoskeletal defects, and congenital heart defects (Alman et al., 2017). Although the biological mechanism behind this association is still unknown, it nevertheless suggests that facilitating adequate maternal water consumption early during pregnancy is key to reducing subsequent adverse pregnancy outcomes (Alman et al., 2017). Despite some gains in increasing coverage of piped water access in the uMkhanyakude District, there are some communities where surface water sources continue to be used as a primary water source. For instance, $77.2 \%$ of households surveyed in the Madeya Village still use surface water as a primary water source (Mulopo et al., 2020). Barriers to ensuring access to a clean basic water supply in these communities should be investigated and addressed as a 
medRxiv preprint doi: https://doi.org/10.1101/2021.03.18.21253882; this version posted March 20, 2021. The copyright holder for this preprint (which was not certified by peer review) is the author/funder, who has granted medRxiv a license to display the preprint in perpetuity. It is made available under a CC-BY 4.0 International license.

matter of urgency. It is tempting to propose the use of electric fans and air conditioning as a heat adaptation strategy for households with pregnant women in sub-Saharan African settings. However, this would be unfeasible for several reasons. The increased electricity demand would require the rollout or upgrading of electric power infrastructure (Farbotko and Waitt, 2011), which would be a very costly undertaking in resource constrained sub-Saharan Africa. In addition, many households in the region might be unable to afford electrification (Ismail and Khembo, 2015). Lastly, air conditioning increases environmentally harmful gas emissions, and this can further contribute toward climate change in the region (Farbotko and Waitt, 2011). As such, there remains a need for future research which seeks to establish appropriate interventions for reducing the impact of high ambient temperatures on women's reproductive health and pregnancy outcomes in resource limited sub-Saharan Africa.

Our study had several strengths, the most notable of which was our use of data from one of Africa's largest rural population-based cohorts. We also used consistently measured, accurate temperature data from a regional weather station in our analysis. Lastly, the regular frequency of the AHRI surveys reduced the risk of recall bias around pregnancy outcomes. One of the main limitations of our study was that we were unable to adjust our analysis for the presence of sexually transmitted infections, such as syphilis. Syphilis is associated with an almost 5fold higher risk of pregnancy loss (Gomez et al., 2013). There may also be a possibility that miscarriage and stillbirth was underreported in the rural community. Furthermore, the observed relationship between temperature and pregnancy loss in our study is likely to be ecological and although we adjusted our analysis for as many factors as was possible, there might still have been some factors that follow a similar seasonality to temperature which were not included in our analysis. 
medRxiv preprint doi: https://doi.org/10.1101/2021.03.18.21253882; this version posted March 20, 2021. The copyright holder for this preprint (which was not certified by peer review) is the author/funder, who has granted medRxiv a license to display the preprint in perpetuity.

It is made available under a CC-BY 4.0 International license .

In summary, we report a clear relationship between higher temperatures at conception and pregnancy loss in our sub-Saharan African setting. The effects of global warming will likely exacerbate the current reproductive health challenges faced by women in sub-Saharan Africa. Our study provides evidence for policymakers in South Africa and other countries in the subSaharan African region to give adequate attention to women's reproductive health and pregnancy outcomes when drafting health policies in response to global warming.

\section{Conflict of interest}

None declared.

\section{Acknowledgements}

YM contributed to the study's conception, design, statistical analysis, and drafting of the manuscript. FT contributed to the study's conception and drafting of the manuscript. AT contributed to the study's conception, design, acquisition of the temperature data from the South African Weather Services and drafting of the manuscript. All authors read and approved the final version of this manuscript. The authors are grateful to the study participants and the work and support of the fieldwork and database teams at AHRI. We would also like to thank the South African Weather Services for providing us access to their dataset. The corresponding author was supported with a postdoctoral fellowship under a National Institute of Health (NIH) grant (R01 HD084233). The Africa Health Research Institute's Demographic Surveillance Information System and Population Intervention Programme is funded by the Wellcome Trust (201433/Z/16/Z), and the South African Population Research Infrastructure Network (funded by the South African Department of 
medRxiv preprint doi: https://doi.org/10.1101/2021.03.18.21253882; this version posted March 20, 2021. The copyright holder for this preprint (which was not certified by peer review) is the author/funder, who has granted medRxiv a license to display the preprint in perpetuity.

It is made available under a CC-BY 4.0 International license .

Science and Technology and hosted by the South African Medical Research Council). The funders played no role in designing the study; in the collection, analysis and interpretation of data; in the writing of the report; and in the decision to submit the article for publication. The content of this manuscript is solely the responsibility of the authors and does not necessarily represent the official views of the funding bodies.

\section{References}

Alman, B.L., Coffman, E., Siega-Riz, A.M., Luben, T.J., 2017. Associations between Maternal Water Consumption and Birth Defects in the National Birth Defects Prevention Study (2000-2005). Birth Defects Res. 109, 193-202. https://doi.org/10.1002/bdra.23569.

Bekkar, B., Pacheco, S., Basu, R., DeNicola, N., 2020. Association of Air Pollution and Heat Exposure With Preterm Birth, Low Birth Weight, and Stillbirth in the US: A Systematic Review. JAMA Netw. Open. 3, e208243. https://doi.org/10.1001/jamanetworkopen.2020.8243.

Chersich, M.F., Wright, C.Y., Venter, F., Rees, H., Scorgie, F., Erasmus, B., 2018. Impacts of Climate Change on Health and Wellbeing in South Africa. Int. J. Environ. Res. Public Health.15, 1884. https://doi.org/10.3390/ijerph15091884.

Chetty, T., Thorne, C., Tanser, F., Bärnighausen, T., Coutsoudis, A., 2016. Cohort profile: the Hlabisa pregnancy cohort, KwaZulu-Natal, South Africa. BMJ Open. 6, e012088. https://doi.org/10.1136/bmjopen-2016-012088.

Chetty, T., Vandormael, A., Thorne, C., Coutsoudis, A., 2017. Incident HIV during pregnancy and early postpartum period: a population-based cohort study in a rural 
medRxiv preprint doi: https://doi.org/10.1101/2021.03.18.21253882; this version posted March 20, 2021. The copyright holder for this preprint (which was not certified by peer review) is the author/funder, who has granted medRxiv a license to display the preprint in perpetuity.

It is made available under a CC-BY 4.0 International license .

area in KwaZulu-Natal, South Africa. BMC Pregnancy Childbirth. 17, 248.

https://doi.org/10.1186/s12884-017-1421-6.

Farbotko, C., Waitt, G., 2011. Residential air-conditioning and climate change: voices of the vulnerable. Health Promot. J. Austr. 22, 13-15.

Garland, R.M., 2014. National policy response to climate change in South Africa. S. Afr. Med. J. 104, 584. https://doi.org/10.7196/samj.8605.

Gomez, G.B., Kamb, M.L., Newman, L.M., Mark, J., Broutet, N., Hawkes, S.J., 2013.

Untreated maternal syphilis and adverse outcomes of pregnancy: a systematic review and meta-analysis. Bull. World Health Organ. 91, 217-26.

https://doi.org/10.2471/BLT.12.107623.

Ismail, Z., Khembo, P., 2015. Determinants of energy poverty in South Africa. J. Energy

South Afr. 26, 66-78.

Kuehn, L., McCormick, S., 2017. Heat Exposure and Maternal Health in the Face of Climate Change. Int. J. Environ. Res. Public Health. 14, 853.

https://doi.org/10.3390/ijerph14080853.

Mbokodo, I., Bopape, M-J., Chikoore, H., Engelbrecht, F., Nethengwe, N., 2020. Heatwaves in the future warmer climate of South Africa. Atmosphere. 11, 712. https://doi.org/10.3390/atmos11070712.

Moodley, Y., Tomita, A., de Oliveira, T., Tanser, F., 2021. HIV viral load and pregnancy loss: Results from a population-based cohort study in rural KwaZulu-Natal, South Africa. AIDS (In press).

Morgenthal, T.L., Kellner, K., van Rensburg, L., Newby, T.S., van der Merwe, J.P.A., 2006. Vegetation and habitat types of the Umkhanyakude Node. South African Journal of Botany. 72, 1-10. https://doi.org/10.1016/j.sajb.2005.03.003. 
medRxiv preprint doi: https://doi.org/10.1101/2021.03.18.21253882; this version posted March 20, 2021. The copyright holder for this preprint (which was not certified by peer review) is the author/funder, who has granted medRxiv a license to display the preprint in perpetuity.

It is made available under a CC-BY 4.0 International license .

Mulopo, C., Kalinda, C., Chimbari, M.J., 2020. Contextual and Psychosocial Factors

Influencing the Use of Safe Water Sources: A Case of Madeya Village, uMkhanyakude District, South Africa. Int. J. Environ. Res. Public Health. 17, 1349. https://doi.org/10.3390/ijerph17041349.

Ngwenya, N., Gumede, D., Shahmanesh, M., McGrath, N., Grant, A., Seeley, J., 2018. Community perceptions of the socio-economic structural context influencing HIV and TB risk, prevention and treatment in a high prevalence area in the era of antiretroviral therapy. Afr. J. AIDS Res. 17, 72-81. https://doi.org/10.2989/16085906.2017.1415214.

Russo, S., Marchese, A.F., Sillmann, J., Immé, G., 2016. When will unusual heat waves become normal in a warming Africa? Environ. Res. Lett. 11, 054016. https://doi.org/10.1088/1748-9326/11/5/054016.

South African Human Rights Commission, 2018. The right to water and sanitation. https://www.sahrc.org.za/home/21/files/SAHRC\%20Water\%20and\%20Sanitation\%2 Orevised\%20pamphlet\%2020\%20March\%202018.pdf. (accessed 23.12.20).

Tanser, F., Hosegood, V., Bärnighausen, T., Herbst, K., Nyirenda, M., Muhwava, W., Newell, C., Viljoen, J., Mutevedzi, T., Newell, ML., 2008. Cohort Profile: Africa Centre Demographic Information System (ACDIS) and population-based HIV survey. Int. J. Epidemiol. 37, 956-962. https://doi.org/10.1093/ije/dym211.

Tlou, B., Sartorius, B., Tanser, F., 2017. Space-time patterns in maternal and mother mortality in a rural South African population with high HIV prevalence (2000-2014): results from a population-based cohort. BMC Public Health. 17, 543. https://doi.org/10.1186/s12889-017-4463-9.

Vandormael, A., Akullian, A., Siedner, M., de Oliveira, T., Bärnighausen, T., Tanser, F., 2019. Declines in HIV incidence among men and women in a South African 
medRxiv preprint doi: https://doi.org/10.1101/2021.03.18.21253882; this version posted March 20, 2021. The copyright holder for this preprint (which was not certified by peer review) is the author/funder, who has granted medRxiv a license to display the preprint in perpetuity.

It is made available under a CC-BY 4.0 International license.

population-based cohort. Nat. Commun. 10, 5482. https://doi.org/10.1038/s41467-

019-13473-y.

Weber, T., Haensler, A., Rechid, D., Pfeifer, S., Eggert, B., Jacob, D., 2018. Analyzing

regional climate change in Africa in a $1.5,2$, and $3^{\circ} \mathrm{C}$ global warming world. Earth's

Future. 6, 643-655. https://doi.org/10.1002/2017EF000714. 
medRxiv preprint doi: https://doi.org/10.1101/2021.03.18.21253882; this version posted March 20, 2021. The copyright holder for this preprint (which was not certified by peer review) is the author/funder, who has granted medRxiv a license to display the preprint in perpetuity.

It is made available under a CC-BY 4.0 International license.

Fig. 1. Location of the uMkhanyakude District, South Africa

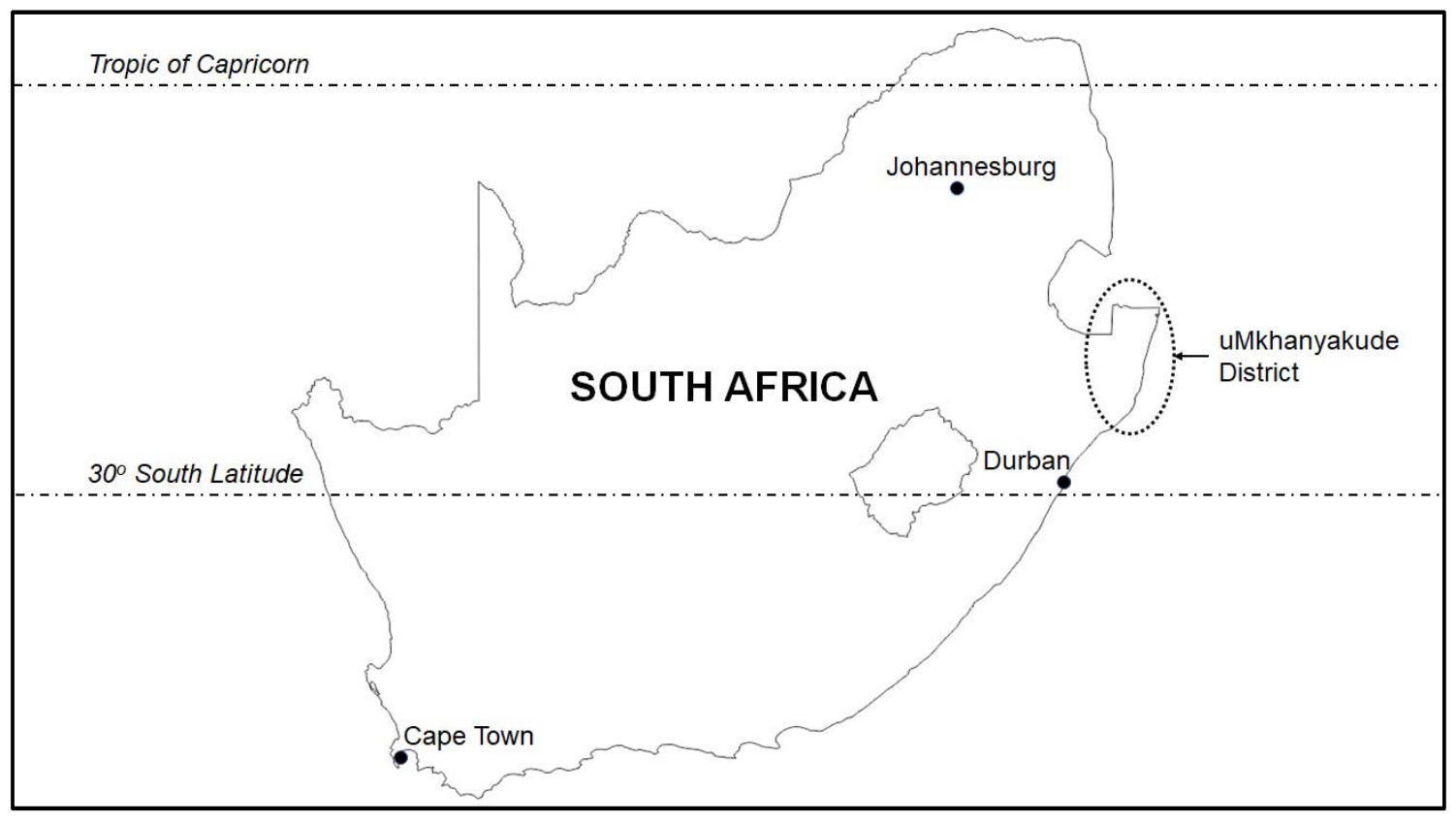


medRxiv preprint doi: https://doi.org/10.1101/2021.03.18.21253882; this version posted March 20, 2021. The copyright holder for this preprint (which was not certified by peer review) is the author/funder, who has granted medRxiv a license to display the preprint in perpetuity.

It is made available under a CC-BY 4.0 International license.

Table 1. Description of the study sample

\begin{tabular}{|c|c|}
\hline Characteristic & $n(\%$ of $N=36341)$ \\
\hline \multicolumn{2}{|l|}{ Pregnancy characteristics } \\
\hline \multicolumn{2}{|c|}{ Year pregnancy was conceived } \\
\hline 2000 & $2457(6.8)$ \\
\hline 2001 & $2375(6.5)$ \\
\hline 2002 & $2364(6.5)$ \\
\hline 2003 & $2346(6.4)$ \\
\hline 2004 & $2514(6.9)$ \\
\hline 2005 & $2344(6.5)$ \\
\hline 2006 & $2347(6.4)$ \\
\hline 2007 & $2285(6.3)$ \\
\hline 2008 & $2221(6.1)$ \\
\hline 2009 & $2060(5.7)$ \\
\hline 2010 & $2024(5.6)$ \\
\hline 2011 & $1746(4.8)$ \\
\hline 2012 & $1787(4.9)$ \\
\hline 2013 & $1603(4.4)$ \\
\hline 2014 & $1553(4.3)$ \\
\hline 2015 & $1268(3.5)$ \\
\hline 2016 & $1807(5.0)$ \\
\hline 2017 & $1240(3.4)$ \\
\hline \multicolumn{2}{|l|}{ Pregnancy loss } \\
\hline No & $35662(98.1)$ \\
\hline Yes & $679(1.9)$ \\
\hline \multicolumn{2}{|c|}{ Temperature variable } \\
\hline \multicolumn{2}{|c|}{ Temperature at conception in ${ }^{\circ} \mathrm{C}$} \\
\hline Mean $(95 \% \mathrm{CI})$ & $27.49(27.47-27.52)$ \\
\hline \multicolumn{2}{|c|}{ Maternal characteristics } \\
\hline \multicolumn{2}{|c|}{ Age at conception in years } \\
\hline \multirow{2}{*}{\multicolumn{2}{|c|}{ Number of prior pregnancies }} \\
\hline & \\
\hline Mean $(95 \%$ CI $)$ & $0.99(0.98-1.01)$ \\
\hline \multicolumn{2}{|c|}{ Prior history of pregnancy loss } \\
\hline No & $35362(97.3)$ \\
\hline Yes & $979(2.7)$ \\
\hline \multicolumn{2}{|l|}{ Low socioeconomic status } \\
\hline No & $11897(32.7)$ \\
\hline Yes & $24444(67.3)$ \\
\hline \multicolumn{2}{|c|}{ Attended all routine antenatal clinic visits } \\
\hline Could not be established & $18400(50.6)$ \\
\hline No & 17419 (47.9) \\
\hline Yes & $522(1.4)$ \\
\hline \multicolumn{2}{|c|}{ Completed primary school education } \\
\hline No & $17224(47.4)$ \\
\hline Yes & $19117(52.6)$ \\
\hline \multicolumn{2}{|l|}{ Married } \\
\hline No & $34662(94.8)$ \\
\hline Yes & $1879(5.2)$ \\
\hline \multicolumn{2}{|l|}{ HIV serostatus } \\
\hline Could not be established & $24421(67.2)$ \\
\hline Negative & $9009(24.8)$ \\
\hline Positive & $2911(8.0)$ \\
\hline \multicolumn{2}{|c|}{ History of tuberculosis infection } \\
\hline No & $36115(99.4)$ \\
\hline Yes & $226(0.6)$ \\
\hline
\end{tabular}

95\% CI: 95\% Confidence interval. 
medRxiv preprint doi: https://doi.org/10.1101/2021.03.18.21253882; this version posted March 20, 2021. The copyright holder for this preprint (which was not certified by peer review) is the author/funder, who has granted medRxiv a license to display the preprint in perpetuity.

It is made available under a CC-BY 4.0 International license.

Table 2. Results of the univariate and multivariate logistic regression analyses investigating the relationship between temperature at conception, various covariates, and pregnancy loss

\begin{tabular}{|c|c|c|}
\hline Characteristic & Unadjusted OR (95\% CI) & Adjusted OR (95\% CI) \\
\hline \multicolumn{3}{|l|}{ Temperature variable } \\
\hline Temperature at conception (per $1^{\circ} \mathrm{C}$ increase) & $1.05(1.02-1.09)$ & $1.04(1.01-1.08)$ \\
\hline \multicolumn{3}{|l|}{ Maternal characteristics } \\
\hline Age at conception (per 1-year increase) & $1.01(1.00-1.03)$ & $1.01(0.99-1.03)$ \\
\hline Number of prior pregnancies (per additional pregnancy) & $1.05(0.99-1.11)$ & $0.47(0.41-0.53)$ \\
\hline \multicolumn{3}{|l|}{ Prior history of pregnancy loss } \\
\hline No & 1.00 & 1.00 \\
\hline Yes & $69.98(58.97-83.04)$ & $226.93(176.64-291.53)$ \\
\hline \multicolumn{3}{|l|}{ Low socioeconomic status } \\
\hline No & 1.00 & 1.00 \\
\hline Yes & $1.21(1.03-1.43)$ & $1.05(0.85-1.31)$ \\
\hline \multicolumn{3}{|l|}{ Attended all routine antenatal clinic visits } \\
\hline Could not be established & 1.00 & 1.00 \\
\hline No & $1.64(1.40-1.91)$ & $1.74(1.44-2.10)$ \\
\hline Yes & $0.66(0.27-1.60)$ & $0.59(0.22-1.60)$ \\
\hline \multicolumn{3}{|l|}{ Completed primary school education } \\
\hline No & 1.00 & 1.00 \\
\hline Yes & $0.88(0.76-1.03)$ & $0.99(0.81-1.20)$ \\
\hline \multicolumn{3}{|l|}{ Married } \\
\hline No & 1.00 & 1.00 \\
\hline Yes & $0.94(0.66-1.33)$ & $1.04(0.67-1.61)$ \\
\hline \multicolumn{3}{|l|}{ HIV serostatus } \\
\hline Could not be established & 1.00 & 1.00 \\
\hline Negative & $0.79(0.65-0.95)$ & $0.93(0.73-1.18)$ \\
\hline Positive & $0.88(0.66-1.18)$ & $0.91(0.63-1.31)$ \\
\hline \multicolumn{3}{|l|}{ History of tuberculosis infection } \\
\hline No & 1.00 & 1.00 \\
\hline Yes & $1.69(0.79-3.59)$ & $1.74(0.63-4.80)$ \\
\hline
\end{tabular}

OR: Odds ratio, 95\% CI: 95\% Confidence interval. Reference category ORs $=1.00$. 